ORIGINAL ARTICLE

\title{
Stability of jabuticaba flakes obtained by drum drying with cassava starch as additive
}

\section{Estabilidade de flocos de jabuticaba obtidos por secagem em cilindro rotativo usando fécula de mandioca como aditivo}

\author{
Larissa Peixoto Nunes ${ }^{1}$, Vanessa Martins da Silva², Elaine de Cássia Guerreiro Souza1, \\ Cristhiane Caroline Ferrari ${ }^{{ }^{*}}$ (D), Silvia Pimentel Marconi Germer ${ }^{1}$ \\ ${ }^{1}$ Instituto de Tecnologia de Alimentos - ITAL, Centro de Tecnologia de Frutas e Hortaliças - FRUTHOTEC, \\ Campinas/SP - Brasil \\ ${ }^{2}$ Universidade Estadual de Campinas - UNICAMP, Faculdade de Engenharia de Alimentos - FEA, Departmento de \\ Engenharia de Alimentos - DEA, Campinas/SP - Brasil
}

${ }^{*}$ Corresponding Author: Cristhiane Caroline Ferrari, Instituto de Tecnologia de Alimentos - ITAL, Centro de Tecnologia de Frutas e Hortaliças - FRUTHOTEC, Av. Brasil, 2880, CEP: 13070-178, Campinas/SP - Brasil, e-mail: criscaferrari@gmail.com

Cite as: Nunes, L. P., Silva, V. M., Souza, E. C. G., Ferrari, C. C., \& Germer, P. M. (2021). Stability of jabuticaba flakes obtained by drum drying with cassava starch as additive. Brazilian Journal of Food Technology, 24, e2020085. https://doi.org/10.1590/1981-6723.08520

\begin{abstract}
The stability of jabuticaba flakes produced by drum drying using cassava starch as additive was evaluated. Sorption isotherms at $25{ }^{\circ} \mathrm{C}$ were determined. Samples were stored under controlled conditions (relative humidity $=60 \%$, temperature $=20,25$ and $35^{\circ} \mathrm{C}$ ) for until 235 days. The anthocyanin content and color parameters $\left(\mathrm{L}^{*}, \mathrm{a}^{*}\right.$ and $\left.\mathrm{b}^{*}\right)$ were monitored. GAB model led to the best adjustment of sorption isotherm, with a monolayer moisture value of $0.1596 \mathrm{~g}$ water/g dry basis. The visual observations did not point out agglomerations and darkening at $\mathrm{a}_{\mathrm{w}}$ values higher than 0.33 at $25^{\circ} \mathrm{C}$, which can be considered the critical point. The degradation of anthocyanin and color parameters followed first and zero-order kinetic model, respectively. The half-life times (630 to 1450 days) showed good stability at $25^{\circ} \mathrm{C}$, while the temperature acceleration coefficient $\left(2.2 \leq \mathrm{Q}_{10} \leq 3.2\right)$ and activation energy $\left(15 \leq \mathrm{E}_{\mathrm{a}} \leq 19 \mathrm{kcal} / \mathrm{mol}\right)$ values demonstrated a high-temperature sensitivity.
\end{abstract}

Keywords: Sorption isotherm; Anthocyanin; Physicochemical properties; Kinetic; Storage; Myrciaria sp.

\section{Resumo}

A estabilidade dos flocos de jabuticaba produzidos por drum drying usando fécula de mandioca foi avaliada. Isotermas de sorção a $25^{\circ} \mathrm{C}$ foram determinadas e as amostras foram armazenadas sob condições controladas (umidade relativa $=60 \%$ e temperatura $=20,25$ e $35^{\circ} \mathrm{C}$ ) até 235 dias. $O$ teor de anticianinas e os parâmetros de cor $\left(L^{*}, a^{*}\right.$ e $\left.b^{*}\right)$ foram monitorados. $O$ modelo de $G A B$ teve o melhor ajuste das isotermas de sorção, com um teor de umidade da monocamada de $0,1596 \mathrm{~g}$ água/g base seca. A avaliação visual das amostras não mostrou aglomeração e escurecimento para $\mathrm{a}_{\mathrm{w}} \leq 0,33$ a $25^{\circ} \mathrm{C}$, o que pode ser considerado o ponto crítico. A degradação de antocianinas e dos parâmetros de cor seguiu uma cinética de ordem zero e primeira ordem, respectivamente. Os tempos de meia vida (630 a 1450 dias) apresentaram boa estabilidade a $25^{\circ} \mathrm{C}$, enquanto que os valores do fator de 
aceleração das reações com a temperatura $\left(2,2 \leq \mathrm{Q}_{10} \leq 3,2\right)$ e a energia de ativação $\left(15 \leq \mathrm{E}_{\mathrm{a}} \leq 19 \mathrm{kcal} / \mathrm{mol}\right)$ demonstraram uma alta sensibilidade do produto com a temperatura.

Palavras-chave: Isoterma de sorção; Antocianinas; Propriedades físico-químicas; Cinética; Armazenamento; Myrciaria sp.

\section{Introduction}

Jabuticabeira (Myrciaria sp.) is a subtropical Brazilian tree, native to the Atlantic Forest Biome. Jabuticaba, a grape-like fruit, has its trade compromised by the short harvest period (August-November), and postharvest life of up to 3 days. The fruit has low caloric value $(\sim 58 \mathrm{kcal} / 100 \mathrm{~g})$, with a high antioxidant capacity, being rich in nutrients such as minerals (phosphorus, magnesium, calcium, potassium) and phenolic compounds $(\sim 500 \mathrm{mg} / 100 \mathrm{~g})$, in which the main is anthocyanins $(\sim 60 \mathrm{mg} / 100 \mathrm{~g})$. In addition, jabuticabas contain amino acids such as tryptophan and lysine, as well as volatile compounds, and tannins (gallotannins and ellagitannins) (Wu et al., 2013; Oliveira et al., 2018). Studies pointed out the biological effects of jabuticaba peel extract, such as antimicrobial, as well as a preventive effect on diabetes and obesity control (Wu et al., 2013). Jabuticaba is consumed fresh and locally, and is also used in jelly, liqueurs and wines productions. However, there is a growing interest in fruit, whose pulp has been commercially demanded to some products such as ice cream, nectars and yogurts. In the process, whole fruits are cooked before depulping in order to soften the peels, extracting their nutrients.

Drum drying is one of the viable drying processes, showing good results for fruits (Caparino et al., 2012; Tonin et al., 2018; Yamato et al., 2020). The drum drying has some advantages such as high nutrient retention, high energy efficiency and profitability. This technique is interesting mainly for fruit powder or flakes production, since it requires smaller amount of additives ( $<20 \%$ dry basis) in comparison to spray drying ( $50 \%$ d.b.) (Barbosa-Cánovas et al., 2005). On the other hand, drum drying is also a good alternative compared to freeze drying and hot air drying, since freeze drying is an expensive process and hot air drying involves long process times, which is not suitable to liquid/paste raw materials (Nindo \& Tang, 2007; Karam et al., 2016).

The use of process additives in drum drying is required to increase the solids content, improving the thermoplastic characteristics of the film, and making drying easier (Tonin et al., 2018). Moreover, this use increases the glass transition temperature of the dried product, providing greater stability along the storage (Bhandari et al., 1997). Different additives can be used in drum drying, such as starch, maltodextrin and gum Arabic. Nunes et al. (2020) reported the use of corn starch (20\% d.b.) in the drum drying of jabuticaba pulp.

Cassava starch, also known as tapioca, is extracted from the root of cassava and can be used as an additive in drum drying. It is rich in starch, mainly amylopectin, and presents as a white, tasteless and odorless powder (Garcia \& Franco, 2015). Cassava is a Brazilian native plant, and the country is one of the largest producers of cassava starch. Tapioca has been employed as a process additive in acai pulp spray drying (Tonon et al., 2009). Nevertheless, this application is still poorly studied.

The stability of dried food is related to water activity. The sorption isotherm, which correlates moisture content and water activity in equilibrium, at a given temperature, is a useful tool to provide information about the interaction of water and solid porous structure. Furthermore, studies regarding the storage stability are important to better understand the degradations mechanisms and to obtain the kinetic parameters for the shelflife estimation. The degradation behavior of nutrients and quality parameters of dried products all over the storage has been stated in the literature for different drying processes (Ferrari et al., 2013; Caparino et al., 2017). However, the behavior of drum-dried jabuticaba flakes at the storage has not been reported yet.

In this context, the purpose of the current work was to study the stability of the jabuticaba flakes produced by drum drying using cassava starch as the main additive regarding the influence of the relative humidities and the storage temperature in terms of anthocyanin content and changes in color. 


\section{Materials and methods}

\subsection{Materials}

Jabuticaba pulp (Sabará variety) was obtained from De Marchi Indústria e Comércio de Frutas Ltda. (Jundiaí, Brazil). Table 1 shows the physicochemical properties of the raw material. The pulp was stored in a freezer at $-18{ }^{\circ} \mathrm{C}$ (Electrolux, São Paulo, Brazil) and thawed at room temperature for the drying trials. The process additives were cassava starch (tapioca) (General Mills, São Bernardo do Campo, Brazil) and glyceryl monostearate (Synth, Diadema, Brazil).

Table 1. Physicochemical properties of jabuticaba pulp and drum-dried jabuticaba flakes obtained with cassava starch.

\begin{tabular}{|c|c|c|}
\hline Analysis & Pulp & Flakes \\
\hline Moisture content & $90.63 \pm 0.09$ g/100 g w.b. & $1.87 \pm 0.15 \mathrm{~g} / 100$ g w.b. \\
\hline Total sugars & $6.97 \pm 0.19 \mathrm{~g} / 100 \mathrm{~g}$ w.b. & $*$ \\
\hline Reducing sugars & $5.42 \pm 0.04 \mathrm{~g} / 100 \mathrm{~g}$ w.b. & * \\
\hline Non-reducing sugars & $1.55 \pm 0.21 \mathrm{~g} / 100 \mathrm{~g}$ w.b. & * \\
\hline Inverted sugars & $7.05 \pm 0.20$ g/100 g w.b. & $*$ \\
\hline Anthocyanin content & $158.24 \pm 2.5 \mathrm{mg} / 100 \mathrm{~g}$ d.b. & $98.45 \pm 0.92 \mathrm{mg} / 100 \mathrm{~g}$ d.b. \\
\hline Total phenolic compounds & $2887.30 \pm 43.50 \mathrm{mg} \mathrm{GAE} / 100 \mathrm{~g}$ d.b. & $3086.10 \pm 85.92 \mathrm{mg} \mathrm{GAE} / 100 \mathrm{~g}$ d.b. \\
\hline \multicolumn{3}{|c|}{ Antioxidant capacity } \\
\hline DPPH & $311.17 \pm 9.80 \mu \mathrm{mol} \mathrm{TE} / \mathrm{g}$ d.b. & $218.78 \pm 1.95 \mu \mathrm{mol} \mathrm{TE} / \mathrm{g}$ d.b. \\
\hline ABTS & $342.73 \pm 21.49 \mu \mathrm{mol} \mathrm{TE} / \mathrm{g}$ d.b. & $220.96 \pm 6.28 \mu \mathrm{mol} \mathrm{TE} / \mathrm{g}$ d.b. \\
\hline Water activity $\left(\mathrm{a}_{\mathrm{w}}\right)$ & $0.995 \pm 0.001$ & $0.275 \pm 0.002$ \\
\hline $\mathrm{L}^{*}$ & $25.88 \pm 0.69$ & $27.75 \pm 0.63$ \\
\hline$a^{*}$ & $15.12 \pm 0.23$ & $19.3 \pm 0.16$ \\
\hline$b^{*}$ & $3.41 \pm 0.07$ & $5.07 \pm 0.08$ \\
\hline
\end{tabular}

*analyses only performed in the raw material.

\subsection{Pulp preparation and drum drying}

The thawed pulp was homogenized in a colloidal mill (REX2-AL, Meteor, São Paulo, Brazil), and during the operation, the additives were added: $20 \%$ (d.b.) of cassava starch and $0.5 \%$ (d.b.) of glyceryl monostearate. The material was dehydrated in a drum dryer (D139, Richard Simon \& Sons, Nottingham, England) provided with two application cylinders, and a drying area of approximately $0.5 \mathrm{~m}^{2}$ (Nunes, 2019). The definition of the process conditions was based on a previous study with mango pulp (Tonin et al., 2018) and preliminary tests: clearance of $0.15 \mathrm{~mm}$ (between the heating and applicator cylinder), pool level of $400 \mathrm{~mL}$, residence time of approximately 19 seconds and temperature of $141^{\circ} \mathrm{C}$. The dried product, obtained as a film, was flocculated (S508, Fabbe, São Paulo, Brazil) using a $2.5 \mathrm{~mm}$ sieve. The flakes were evaluated regarding the sorption isotherms and stability under controlled storage.

\subsection{Sorption Isotherms}

Saturated solutions of different salts were prepared [ $\mathrm{LiCl}, \mathrm{CH}_{3} \mathrm{COOK}, \mathrm{MgCl}_{2}, \mathrm{~K}_{2} \mathrm{CO}_{3}, \mathrm{Mg}\left(\mathrm{NO}_{3}\right)_{2}, \mathrm{KI}$, $\mathrm{NaCl}, \mathrm{KCl}$ ] to provide relative humidity values between $11 \%$ and $84 \%$ (Greenspan, 1977). About $1 \mathrm{~g}$ of the 
drum-dried jabuticaba flakes was weighed, in triplicate, in aluminum vials, and equilibrated with these solutions. The containers were stored at room temperature $\left(25^{\circ} \mathrm{C}\right)$. Samples were weighed periodically until they reached equilibrium (33 days), with mass variation $< \pm 0.0001$. Along the time, samples were also observed visually with respect to the color, occurrence of caking (agglomeration) and microbial growth. The vials containing the samples stored at different water activities were photographed together and the comparisons between samples were made through the observations and the obtained photos.

The mathematical models of GAB, BET, Halsey, Oswin and Henderson (Park et al., 2001; Tonon et al., 2009) were adjusted to the experimental data using Statistica ${ }^{\circledR} 8.0$ software (StatSoft Inc., Tulsa, USA) by non-linear regression, according to Nunes et al. (2020). The fit to the model was evaluated based on the coefficients of determinations $\left(\mathrm{R}^{2}\right)$, the mean relative percentage deviation (P) (Equation 1) and the estimated Standard Error (SE) (Equation 2).

$$
\begin{aligned}
& P=\frac{100}{N} \sum_{i=1}^{N} \frac{\left|V_{E}-V_{P}\right|}{V_{E}} \\
& S E=\sqrt{\frac{\sum_{i=1}^{n}\left(V_{P}-V_{E}\right)^{2}}{n}}
\end{aligned}
$$

where: $V_{E}=$ experimental values; $V_{P}=$ predicted values; $N=$ number of experimental observations.

\subsection{Stability under controlled storage}

The jabuticaba flakes were packed in a polyester/aluminum/low-density polyethylene (PET/Al/LDPE) bags with a nominal thickness of $70 \mu \mathrm{m}$. The packages were stored in climatic chambers (LS370, Logen Scientific, Brazil) at temperatures of 20,25 and $35^{\circ} \mathrm{C}$, at $65 \%$ Relative Humidity (RH). The product was initially analyzed with respect to moisture content, water activity, instrumental color, anthocyanin content, total phenolic compounds and antioxidant capacity. The analytical methods were described later. Anthocyanin and color analyses were performed according to the storage temperature as follows: every 20 days at $20^{\circ} \mathrm{C}$ for 235 days; every 16 days at $25^{\circ} \mathrm{C}$ for 180 days; every 10 days at $35^{\circ} \mathrm{C}$ for 106 days. One package was used for each analysis at each period and temperature. The analyses were performed at least in triplicate.

Changes in the color parameters and anthocyanin content were evaluated using the zero and first order kinetic models, Equations 3 and 4, respectively, according to Yamato et al. (2020) by regression analysis with Microsoft Excel software (Microsoft, Redmond, USA). The order of the reaction was determined with the best fit to the model, that is, higher $\mathrm{R}^{2}$.

$$
\begin{aligned}
& C_{t}=C_{0}-k t \\
& \ln \frac{C_{t}}{C_{0}}=-k t
\end{aligned}
$$

where: $\mathrm{C}_{0}=$ initial concentration of the component (anthocyanin content or color parameters) at zero time; $\mathrm{C}_{\mathrm{t}}=$ concentration of the component (anthocyanin content or color parameters) at time $\mathrm{t} ; \mathrm{t}=$ time (days). Anthocyanin content is expressed as $\mathrm{mg} / 100 \mathrm{~g}$ dry basis; Color parameters are dimensionless; $k=$ the reaction rate constant (unit of concentration $x$ days $^{-1}$ for the Equation 3 and days ${ }^{-1}$ for the Equation 4).

The reaction rates $(k)$ were obtained and the following kinetic parameters were calculated according to Equations 5, 6, 7 and 8 .

$$
\begin{gathered}
Q_{10}=\frac{k_{T}}{k_{T-10}} \\
t_{\frac{1}{2} l i f e}{ }^{0}=\frac{C_{0}}{-2 k}
\end{gathered}
$$




$$
\begin{aligned}
& t_{\frac{1}{2} \text { life }}=\frac{0.693}{-k} \\
& \ln k=\frac{-E_{a}}{R T}+\ln K
\end{aligned}
$$

where: $k_{\mathrm{T}}=$ the reaction rate constant at temperature $\mathrm{T}\left(\right.$ days $^{-1}$ or unit of concentration $\left.\mathrm{x} \mathrm{days}^{-1}\right)$; $k_{\mathrm{T}-10}=$ reaction rate constant at a temperature $10^{\circ} \mathrm{C}$ lower $\left(\right.$ days ${ }^{-1}$ or unit of concentration $\mathrm{x}^{-1 a y s^{-1}}$ ); $\mathrm{C}_{0}=$ initial concentration of the component at zero time; $\mathrm{t}_{1 / 2 \text { life } 0}=$ half-life time for zero order model (days); $\mathrm{t}_{1 / 2 \text { life } 1}=$ half-life time for first order model (days); $\mathrm{Q}_{10}=$ temperature coefficient; $\mathrm{E}_{\mathrm{a}}=$ activation energy $(\mathrm{kcal} / \mathrm{mol}) ; \mathrm{R}=$ gas constant $(0.00198588 \mathrm{kcal} / \mathrm{mol} . \mathrm{K}) ; \mathrm{T}=$ Temperature $(\mathrm{K}) ; K=$ constant.

\subsection{Analythical methods}

\subsubsection{Sugar content}

The reducing, non-reducing and total sugars of the jabuticabva pulp were evaluated according to Munson \& Walker Method (Carvalho et al., 1990).

\subsubsection{Moisture content}

The moisture content was determined gravimetrically. Samples were weighed and dried in a vacuum oven (model RVT 360, Heraeus, São Paulo, Brazil) at $70^{\circ} \mathrm{C}$ for 24 h (Instituto Adolfo Lutz, 2008).

\subsubsection{Water activity $\left(a_{w}\right)$}

Water activity was measured using a digital hygrometer (Aqualab 3 TE, Decagon Devices Inc, Pullman, USA) at $25^{\circ} \mathrm{C}$.

\subsubsection{Color parameters}

Color parameters were obtained with a colorimeter (CR400, Minolta, Osaka, Japan), through the CIELAB system (D65 illuminant). $\mathrm{L}^{*}$ lightness $\left(\mathrm{L}^{*}=0\right.$ for black and $\mathrm{L}^{*}=100$ for white) and chromaticity parameters $\mathrm{a}^{*}$ (green $[-]$ to red $[+]$ ) and $\mathrm{b}^{*}$ (blue $[-]$ to yellow $[+]$ ) were measured.

\subsubsection{Anthocyanin content}

The anthocyanin content of the flakes was determined following the spectrophotometric $\mathrm{pH}$ differential method (Association of Official Analytical Chemists, 2006) which is based on the structural transformation of anthocyanin that occurs with a change in $\mathrm{pH}$ (colored at $\mathrm{pH} 1.0$ and colorless at $\mathrm{pH} 4.5$ ). Absorbance was measured in a spectrophotometer (Agilent Technologies, Cary 60 MY13110012, Richardson, USA) at 520 and $700 \mathrm{~nm}$.

\subsubsection{Total phenolic compounds}

The total phenolic compounds were measured according to the adaptation of Folin Ciocalteau's spectrophotometry method (Benvenuti et al., 2004). Absorbance readings were done at $750 \mathrm{~nm}$ in the spectrophotometer (Agilent Technologies, Cary 60 MY13110012, Richardson, USA). 


\subsubsection{Antioxidant Activity (DPPH and ABTS)}

The evaluation of the antioxidant activity by DPPH method (Brand-Williams et al., 1995) is based on the capture of the 2,2-diphenyl-1-picryl-hydrazyl radical (DPPH) by antioxidants, producing a decrease in absorbance at $515 \mathrm{~nm}$, determined using the spectrophotometer (Agilent Technologies, Cary 60 MY13110012, USA). ABTS method is based on the capture of the 2,2'-azino-bis(3-ethylbenzothiazoline6-sulfonic acid) free radical $\left(\mathrm{ABTS}^{+}\right)$which can be generated by a chemical reaction with potassium persulfate (Shui \& Leong, 2006), following the adaptation of the methodology described by Rufino et al. (2007). Absorbance readings were measured at $734 \mathrm{~nm}$ in the spectrophotometer (Agilent Technologies, Cary 60 MY13110012, USA).

\subsection{Statistical analysis}

The results of the different tests were evaluated and compared by Analysis of Variance (ANOVA), using the software STATISTICA ${ }^{\circledR}$ version 8.0 (Statsoft, Inc., USA). Mean separation was determined using the Tukey's test at $5 \%$ level of significance $(p \leq 0.05)$. Correlations between color parameter $\left(L^{*}, a^{*}, b^{*}\right)$ and anthocyanin content were determined using Pearson's Correlation Coefficient Test.

\section{Results and discussion}

\subsection{Sorption isotherms}

According to the visual analysis of the drum-dried jabuticaba flakes at the equilibrium, agglomeration and darkening were observed in some conditions (Figure 1). The product stored at the lowest $\mathrm{a}_{\mathrm{w}}(0.112)$ remained free-flowing until the end of the storage time (33 days) with bright color. The most relevant changes were verified from $\mathrm{a}_{\mathrm{w}}=0.432$, when the flakes showed the first important signs of caking, meaning that this is the critical storage condition. As water activity increased, the flakes gradually became darker and more agglomerated. There was microbial growth in the highest water activity $\left(a_{w}=0.843\right)$.

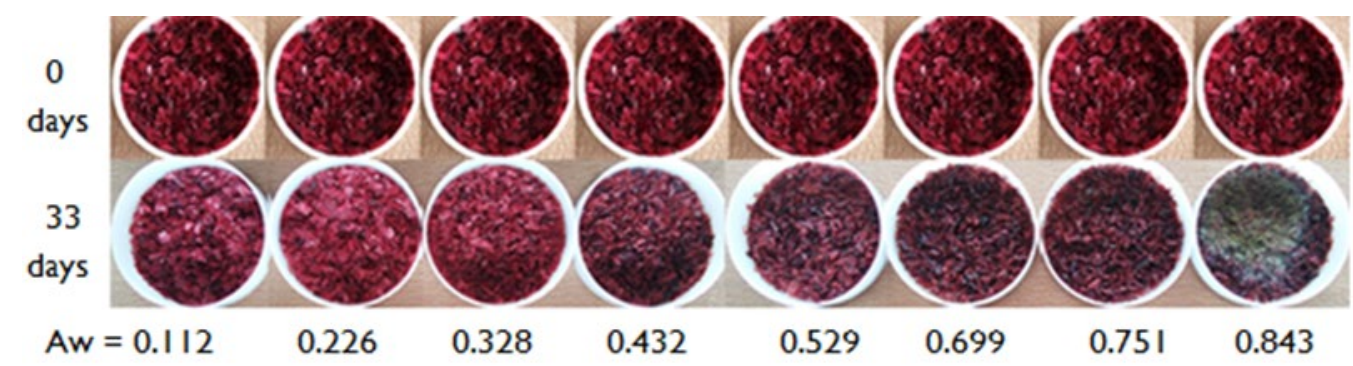

Figure 1. Drum-dried jabuticaba flakes obtained with cassava starch at initial time and at equilibrium (33 days), under different conditions of water activity $\left(\mathrm{a}_{\mathrm{w}}\right)$ and stored at $25^{\circ} \mathrm{C}$.

The parameters obtained for the different mathematical models of sorption isotherms of the drumdried jabuticaba flakes is presented in Table 2. All models had $\mathrm{R}^{2}$ above 0.99 , showing a good fit to the experimental data. Mean relative percentage deviation $(\mathrm{P})$ values lower than $10 \%$ and estimated SE parameter close to zero indicates better representativeness and lower error of the model. Consequently, some models, such as BET, Halsey and Oswin were unsatisfactory. Although Henderson model showed lower $p$ values, the GAB model had the lowest SE value, and then, the lowest error. Nunes et al. (2020) reported similar behavior in the study of the sorption isotherm at $25{ }^{\circ} \mathrm{C}$ of jabuticaba flakes with starch (20\% d.b.). 
Table 2. Parameters for GAB, BET, Halsey, Oswin and Henderson models of sorption isotherms of the drum-dried jabuticaba flakes using cassava starch at $25^{\circ} \mathrm{C}$.

\begin{tabular}{|c|c|c|c|c|c|c|c|}
\hline Model & Equations & & arameter & & $\mathbf{R}^{2}$ & $p(\%)$ & SE \\
\hline \multirow{2}{*}{ GAB } & $M C=\frac{X_{m} \cdot C \cdot K \cdot a_{w}}{}$ & $\mathbf{X}_{\mathrm{m}}$ & $\mathbf{C}$ & $\mathbf{K}$ & \multirow{2}{*}{0.9999} & \multirow{2}{*}{4.50} & \\
\hline & $\left(1-K \cdot a_{w}\right) \cdot\left(1-K \cdot a_{w}+C \cdot K \cdot a_{w}\right)$ & 0.1596 & 0.9692 & 0.8802 & & & 0.23 \\
\hline \multirow{2}{*}{ BET } & \multirow{2}{*}{$M C_{e q}=\frac{X_{m} \cdot C \cdot a_{w}}{\left(1-a_{w}\right)} \cdot\left[\frac{1-(n+1) \cdot\left(a_{w}\right)^{n}+n \cdot\left(a_{w}\right)^{n+1}}{1-(1-C) \cdot a_{w}-C\left(a_{w}\right)^{n+1}}\right]$} & $\mathbf{X}_{\mathbf{m}}$ & $\mathbf{C}$ & n & \multirow{2}{*}{0.9969} & \multirow{2}{*}{12.70} & \\
\hline & & 52.1187 & 0.0013 & 4.0211 & & & 1.13 \\
\hline \multirow[b]{2}{*}{ Halsey } & \multirow{2}{*}{$M C_{e q}=\left(\frac{-a}{\ln \left(a_{w}\right)}\right)^{1 / b}$} & $\mathbf{A}$ & & b & \multirow[b]{2}{*}{0.9924} & \multirow[b]{2}{*}{35.95} & \\
\hline & & 0.0786 & & 1.0325 & & & 1.78 \\
\hline \multirow{2}{*}{ Oswin } & \multirow{2}{*}{$M C_{e q}=a\left(\frac{a_{w}}{\left(1-a_{w}\right)}\right)^{b}$} & $\mathbf{A}$ & & b & \multirow{2}{*}{0.9981} & \multirow{2}{*}{16.33} & \\
\hline & & 0.1246 & & 0.7832 & & & 0.90 \\
\hline \multirow{2}{*}{ Henderson } & \multirow{2}{*}{$M C_{e q}=\left(\frac{-\ln \left(1-a_{w}\right)}{b}\right)^{1 / a}$} & $\mathbf{A}$ & & b & \multirow{2}{*}{0.9998} & \multirow{2}{*}{1.45} & \\
\hline & & 0.7877 & & 3.5254 & & & 1.82 \\
\hline
\end{tabular}

$\mathrm{MC}_{\mathrm{eq}}=$ equilibrium moisture content ( $\mathrm{g}$ water/g dry basis); $\mathrm{a}_{\mathrm{w}}=$ water activity; $\mathrm{X}_{\mathrm{m}}=$ monolayer moisture content ( $\mathrm{g}$ water/g dry basis); $\mathrm{n}=$ number of molecular layers; $\mathrm{C}, \mathrm{K}, \mathrm{a}, \mathrm{b}=$ constants; $\mathrm{SE}=$ Standard Error

The GAB model fit to the experimental data is shown in Figure 2. The sorption isotherm showed a continuous increase in water absorption as water activity increased, following a sigmoidal format (type III curve). Furthermore, according to the constants $(0<\mathrm{K} \leq 1$ and $0 \leq \mathrm{C} \leq 2)$, the adjusted GAB model can also be classified as type III (Brunauer, 1943). In this case, the equilibrium moisture content slightly increases at low water activities, being faster at $\mathrm{a}_{\mathrm{w}}$ greater than 0.60 . The behavior in this range is due to the predominant effect of solute-solvent interactions associated with sugar dissolution. According to Labuza \& Altunakar (2007), type III isotherm is characteristic of sugar-rich foods. As seen in Table 1, jabuticaba pulp has $7 \mathrm{~g}$ total sugars $/ 100 \mathrm{~g}$, in which about $5 \mathrm{~g} / 100 \mathrm{~g}$ are reducing sugars.

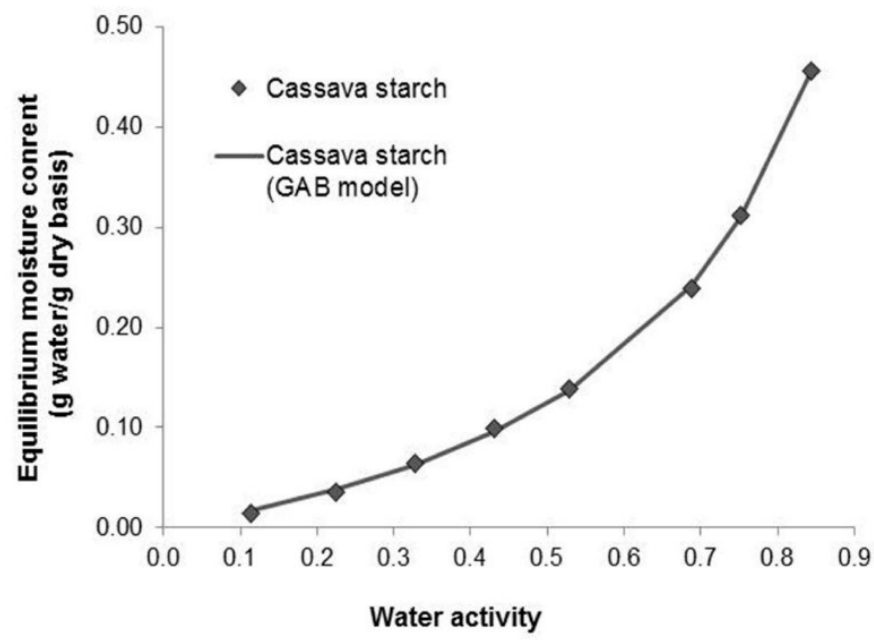

Figure 2. Sorption isotherm of drum-dried jabuticaba flakes with cassava starch at $25^{\circ} \mathrm{C}$ (experimental data and $\mathrm{GAB}$ model). $\mathrm{X}_{\mathrm{m}}=0.1596 \mathrm{~g}$ water/g dry basis; $\mathrm{C}=0.9692 ; \mathrm{K}=0.8802$.

According to the GAB model (Figure 2), the monolayer moisture content $\left(\mathrm{X}_{\mathrm{m}}\right)$ of jabuticaba flakes produced by drum drying with cassava starch was $0.1596 \mathrm{~g}$ water/g dry basis. The monolayer represents the amount of water strongly bound to the solid food matrix and is related to product stability. 
Nunes et al. (2020) reported a very similar value for drum-dried jabuticaba flakes obtained with corn starch (0.1274 g water/g dry basis). On the other hand, López-Vidaña et al. (2016) reported a higher value for jabuticaba flour obtained in a drying chamber with air circulation $\left(\mathrm{X}_{\mathrm{m}}=0.2954 \mathrm{~g}\right.$ water $/ \mathrm{g}$ dry basis) without additives. These differences might be related to the use of additives. According to Kurozawa at al. (2009), the use of biopolymers as additive in drying results in decreasing of $X_{m}$ due to the encapsulation effect, which reduces the surface exposed to water molecules. Different additives can result in different $X_{\mathrm{m}}$ values due to the conformation and topology of molecule and the hydrophilic / hydrophobic sites (Pérez-Alonso et al., 2006).

The $X_{m}$ value obtained using the BET model was 52.11, according to Table 2. Bezerra et al. (2011) and Paglarini et al. (2013) also found $\mathrm{X}_{\mathrm{m}}$ values higher than 30, besides mean relative percentage deviation (P) higher than $20 \%$. It is important to mention that $\mathrm{X}_{\mathrm{m}}$ higher than 1 indicates moisture contents above $100 \%$ and therefore these values shows no physical significance within the monolayer moisture content concept. The parameters of BET model ( $\mathrm{X}_{\mathrm{m}}$ and the constants) were obtained through non-linear regression of the experimental data using the Quasi-Newton adjustment method of the Statistica ${ }^{\circledR}$ software. These iterations continue until the algorithm converges on the smallest residual sum of squares. For the specific case of adjustment to the BET model, many iterations were required for the model converged and $X_{m}$ values found cannot be used to represent the sorption isotherms of drumdried jabuticaba flakes.

\subsection{Kinetics of anthocyanin degradation}

The degradation of anthocyanins in jabuticaba flakes followed a first-order kinetic model over the storage time $\left(0.74<\mathrm{R}^{2}<0.91\right)$, with an initial anthocyanin content around $98 \mathrm{mg} / 100 \mathrm{~g}$ (d.b.) (Table 1). Figure 3 shows the variation of anthocyanin contents along the storage period at different temperatures, while Table 3 presents the obtained kinetic parameters. The degradation of anthocyanin during the storage may be attributed to some mechanisms as the polymerization with other phenolic compounds (Wrolstad et al., 1990) and the interaction with the Maillard reaction products (furfural and hydroxymethylfurfural), forming brown compounds (Pitalua et al., 2010). Some studies with different fruit products have also obtained a first-order kinetic model for anthocyanin degradation: grape juice (Muche et al., 2018); freeze-dried pomegranate peel extract (Azarpazhooh et al., 2019) and spray-dried blackberry powder (Ferrari et al., 2013).

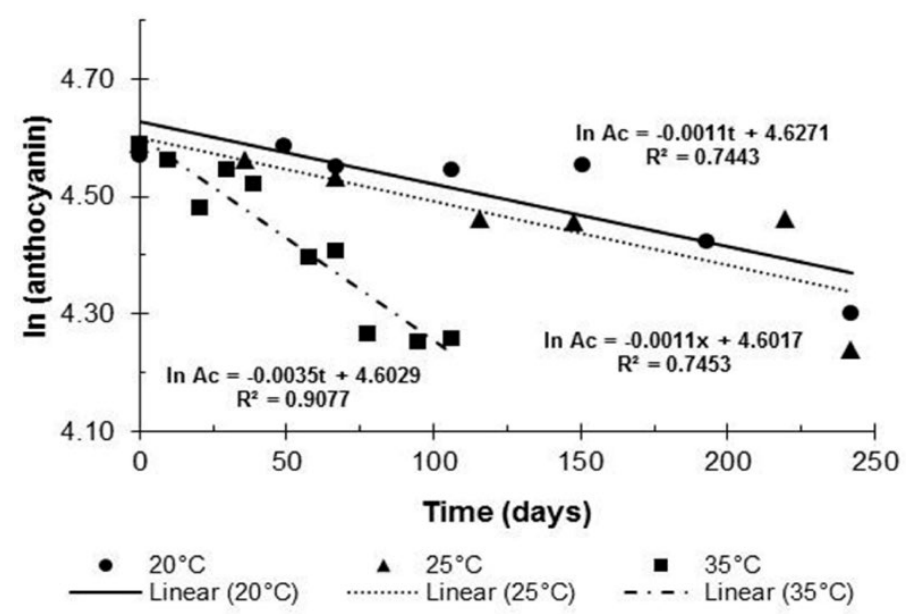

Figure 3. Kinetic of anthocyanin (Ac) degradation (first order reaction) of the drum-dried jabuticaba flakes obtained with cassava starch along the storage at 20,25 and $35^{\circ} \mathrm{C}$, as a function of time $\mathrm{t}$ (days). Anthocyanin content is expressed as $\mathrm{mg} / 100 \mathrm{~g}$ dry basis. 
Table 3. Kinetic parameters of anthocyanin degradation and color variation of drum-dried jabuticaba flakes obtained with cassava starch and stored under different temperatures $(\mathrm{T})$.

\begin{tabular}{|c|c|c|c|c|c|c|c|c|}
\hline $\mathbf{T}\left({ }^{\circ} \mathbf{C}\right)$ & Analysis & $\begin{array}{c}\text { Reaction } \\
\text { Order }\end{array}$ & $\mathbf{k}^{(1)}$ & $\begin{array}{c}\text { Linear } \\
\text { Coefficient }\end{array}$ & $\mathbf{R}^{2}$ & $\mathbf{Q}_{10}$ & $\begin{array}{c}t_{1 / 2} \\
\text { (days) }\end{array}$ & $\begin{array}{c}\mathbf{E}_{\mathbf{a}} \\
\left(\mathrm{kcal} \mathrm{mol}^{-1}\right)\end{array}$ \\
\hline 20 & Anthocyanin & \multirow{3}{*}{1} & -0.0011 & 4.6271 & 0.7443 & - & 630 & \multirow{3}{*}{14.80} \\
\hline 25 & content & & -0.0011 & 4.6017 & 0.7453 & \multirow{2}{*}{3.18} & 630 & \\
\hline 35 & & & -0.0035 & 4.6029 & 0.9077 & & 198 & \\
\hline 20 & & \multirow{3}{*}{0} & -0.0117 & 28.445 & 0.8439 & - & 1216 & \multirow{3}{*}{14.88} \\
\hline 25 & $\mathrm{~L}^{*}$ & & -0.0187 & 27.873 & 0.9517 & \multirow{2}{*}{2.19} & 745 & \\
\hline 35 & & & -0.0409 & 26.502 & 0.8721 & & 324 & \\
\hline 20 & & \multirow{3}{*}{0} & -0.0037 & 19.281 & 0.8275 & - & 2606 & \multirow{3}{*}{19.19} \\
\hline 25 & $a^{*}$ & & -0.0068 & 19.666 & 0.8755 & \multirow{2}{*}{2.74} & 1446 & \\
\hline 35 & & & -0.0186 & 18.653 & 0.8088 & & 501 & \\
\hline 20 & & \multirow{3}{*}{0} & 0.0022 & 5.0396 & 0.9419 & - & 1145 & \multirow{3}{*}{15.11} \\
\hline 25 & $\mathrm{~b}^{*}$ & & 0.0026 & 5.1454 & 0.9597 & \multirow{2}{*}{2.85} & 990 & \\
\hline 35 & & & 0.0074 & 4.8981 & 0.9024 & & 331 & \\
\hline
\end{tabular}

(1) The unit of $k$ in the first order reaction (anthocyanin content) is [days $\left.{ }^{-1}\right]$; in the case of zero order reaction (color parameters) the unit would be [concentration unit $\mathrm{x}$ day $^{-1}$ ]. As the color parameters are dimensionless, the unit of $k$ is also days ${ }^{-1}$.

According to Table 3 , the reaction rate $(k)$ increased with temperature in the drum-dried jabuticaba flakes, ranging from 0.0011 to 0.0035 days $^{-1}$. These values are slightly lower than those reported by Ferrari et al. (2013) in spray-dried blackberry powder with $7 \%(\mathrm{w} / \mathrm{w})$ maltodextrin $\left(0.0019\right.$ and 0.0032 days $^{-1}$ at 25 and $35^{\circ} \mathrm{C}$, respectively).

The half-life time $\left(\mathrm{t}_{1} / 2\right)$ of anthocyanins for the product stored at $25^{\circ} \mathrm{C}$ was 630 days. The reaction rate $(k)$ and the half-life time $\left(\mathrm{t}_{1 / 2}\right)$ is the same at $20^{\circ} \mathrm{C}$, showing that the anthocyanin degradation at 20 and $25^{\circ} \mathrm{C}$ was very similar. The result was higher than that reported for freeze-dried wild blueberry powder (139 days at $25^{\circ} \mathrm{C}$ ) (Fracassetti et al., 2013) and freeze-dried pomegranate extract encapsulated with $15 \%$ maltodextrin (around 102 days at $25{ }^{\circ} \mathrm{C}$ ) (Azarpazhooh et al., 2019). The $\mathrm{t}_{1 / 2}$ value for jabuticaba flakes was reduced to 198 days at a storage temperature of $35^{\circ} \mathrm{C}$.

The $\mathrm{Q}_{10}$ obtained (3.18) indicated a high influence of temperature on anthocyanin degradation. Tonon et al. (2010) reported $\mathrm{Q}_{10}=1.87$ for anthocyanin degradation in atomized acai juice with $6 \%(\mathrm{w} / \mathrm{w})$ of cassava starch and Fracassetti et al. (2013) observed a $\mathrm{Q}_{10}=2.15$ in freeze-dried blueberry. The obtained activation energy in the current work, $14.80 \mathrm{kcal} / \mathrm{mol}(61.97 \mathrm{~kJ} / \mathrm{mol})$, was higher than those pointed out by Fracassetti et al. (2013) for freeze-dried blueberry $(58.26 \mathrm{~kJ} / \mathrm{mol})$ and Muche et al. (2018) for "Ruby" grape juice $(43.49 \mathrm{~kJ} / \mathrm{mol})$. Higher Ea values imply a greater reaction dependence with respect to temperature.

In this context, anthocyanin degradation reaction in the jabuticaba flakes occurred at a slow rate at room temperature, resulting in a relatively long half-life (approximately 1.7 years), as observed in Table 3 . However, the reaction showed high activation energy $\left(\mathrm{E}_{\mathrm{a}}\right)$ and temperature coefficient $\left(\mathrm{Q}_{10}\right)$ values, indicating the high-temperature sensitivity of the anthocyanins.

\subsection{Kinetics of Color Variation $\left(L^{*}, a^{*}, b^{*}\right)$}

The following color parameters were observed in the jabuticaba flakes at the beginning of the storage: $\mathrm{L}^{*}=27.75 ; \mathrm{a}^{*}=19.31 ;$ and $\mathrm{b}^{*}=5.07$ (Table 1 ). The variation in color parameters $\left(\mathrm{L}^{*}, \mathrm{a} *, \mathrm{~b} *\right)$ throughout 
the storage of the flakes was better adjusted by the zero-order model $\left(0.81<\mathrm{R}^{2}<0.96\right)$. Other studies also report zero-order kinetics for color parameters in fruit products: dehydrated papaya (Germer et al., 2014) and mango powder (Yamato et al., 2020). Figure 4 shows the variation of the color parameters along the storage at different temperatures and Table 3 presents the kinetic parameters.

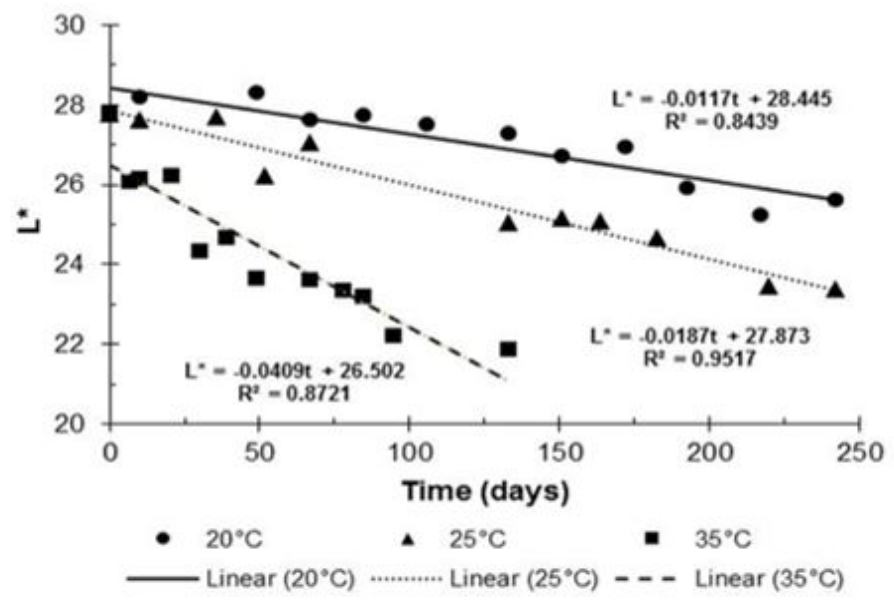

(a)

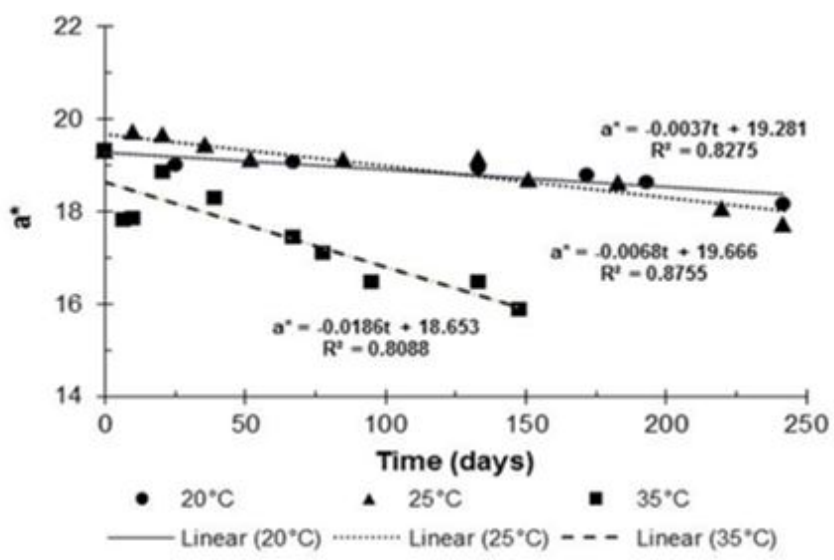

(b)

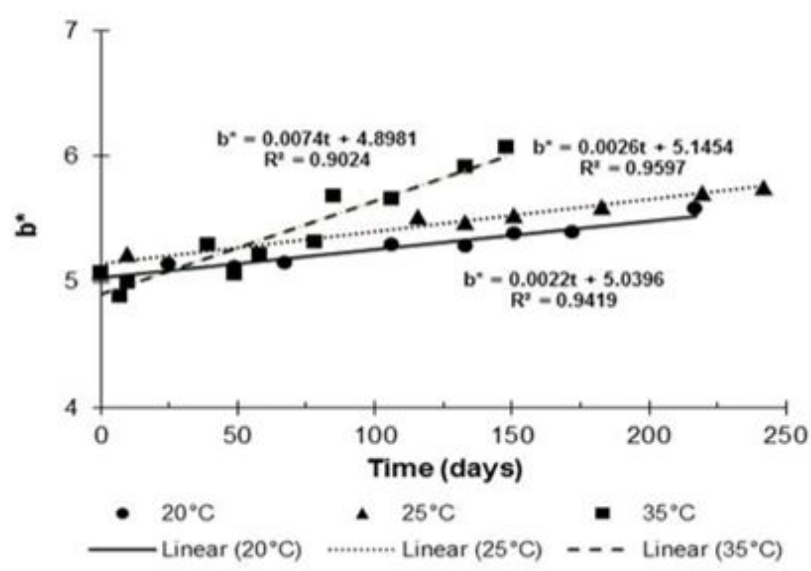

(c)

Figure 4. Kinetic of color variation (zero order reaction) of the drum-dried jabuticaba flakes obtained with cassava starch along the storage at 20,25 and $35^{\circ} \mathrm{C}$, as a function of time $\mathrm{t}$ (days). (a) parameter $\mathrm{L}^{*}$; (b) parameter a*;

(c) parameter $b^{*}$. 
Regarding the lightness $\left(\mathrm{L}^{*}\right)$, there was a reduction over time, indicating a darkening during the storage (Figure 4a). This behavior may be related to the degradation reactions of the anthocyanin as previously discussed. The reaction rate $(k)$ increased from 0.0117 to 0.0409 days $^{-1}$ as temperature increased from 20 to $35^{\circ} \mathrm{C}$ (Table 3 ). Yamato et al. (2020) reported relatively lower k values in the stability study of drum-dried mango flakes with 3\% (d.b.) corn starch $\left(0.0139\right.$ days $^{-1}$ at $25^{\circ} \mathrm{C}$ and 0.0183 days $\left.^{-1}\right)$ at $35^{\circ} \mathrm{C}$. In the current study, $\mathrm{Q}_{10}$ was 2.19 (Table 3), which is higher than that obtained by Yamato et al. (2020) for mango flakes $\left(\mathrm{Q}_{10}=1.31\right)$, showing a greater influence of temperature on the darkening of jabuticaba flakes. The half-life time $\left(\mathrm{t}_{1 / 2}\right)$ of the lightness decreased from 745 days at $25{ }^{\circ} \mathrm{C}$ to 324 days with a $10{ }^{\circ} \mathrm{C}$ increase in the storage temperature (Table 3). The activation energy $\left(E_{a}\right)$ of the lightness in jabuticaba flakes was approximately $15 \mathrm{kcal}^{\mathrm{mol}}{ }^{-1}$.

Parameter $\mathrm{a}^{*}$ (red) was predominant in the instrumental color of the flakes (Table 3 ). This is a characteristic of the jabuticaba pulp obtained after cooking the whole fruit, as previously reported, since the fruit pulp (white) gains pigments from the peel (dark purple). Figure $4 \mathrm{~b}$ shows that $\mathrm{a}^{*}$ decreased with storage time. Flakes stored at $35^{\circ} \mathrm{C}$ had the largest reduction ( $\sim 18 \%$ with respect to the initial values), followed by those stored at $25^{\circ} \mathrm{C}(\sim 8 \%)$ and $20^{\circ}(\sim 6 \%)$. The loss of red color may be attributed to the degradation of anthocyanins during the storage due to the previously mentioned mechanisms. The behavior has also been reported in other studies for anthocyanin-rich products: low-sugar blackberry jam (Moura et al., 2012) and pasteurized strawberry juice (Buvé et al., 2018).

Reaction rates $(k)$ ranged from $0.0037\left(20^{\circ} \mathrm{C}\right)$ to $0.0186\left(35^{\circ} \mathrm{C}\right)$ days $^{-1}$, and half-life time $\left(\mathrm{t}_{1 / 2}\right)$ varied from 2606 to 501 days (Table 3). Buvé et al. (2018) found $k$ value around 0.008 days $^{-1}$ for pasteurized strawberry juice stored at $20^{\circ} \mathrm{C}$. For drum-dried mango flakes, Yamato et al. (2020) obtained $k$ values ranging from 0.0053 days $^{-1}$ to 0.0102 days $^{-1}$ and half-life times of 1212 and 629 days at 25 and $35^{\circ} \mathrm{C}$, respectively. $\mathrm{Q}_{10}$ for the variation of parameter $\mathrm{a}^{*}$ in the current work was 2.74. Yamato et al. (2020) reported $\mathrm{Q}_{10}$ values of 1.92 and 4.34 for mango flakes obtained by drum drying with corn starch and maltodextrin, respectively. On the other hand, activation energy $\left(\mathrm{E}_{\mathrm{a}}\right)$ of jabuticaba flakes $(\sim 19 \mathrm{kcal} / \mathrm{mol})$ was higher than the value reported by Buvé et al. (2018) (13 kcal/mol) for pasteurized strawberry juice.

Concerning the parameter $b^{*}$, there was an increase along the storage (Figure 4c), indicating the increase of the yellow color of jabuticaba flakes over time. This variation may be also associated with anthocyanins degradation, as previously mentioned. Moura et al. (2012) reported the same behavior in their work with lowsugar blackberry jam stored at $10{ }^{\circ} \mathrm{C}$.

In the present study, the reaction rate $(k)$ values were 0.0022 and 0.0074 days $^{-1}$ at 20 and $35^{\circ} \mathrm{C}$, respectively, while half-life times were 1145 days and 331 days at 20 and $35^{\circ} \mathrm{C}$, respectively. The activation energy $\left(E_{a}\right)$ and $\mathrm{Q}_{10}$ values were $15.11 \mathrm{kcal} \mathrm{mol}^{-1}$ and 2.85 (Table 3), respectively, demonstrating a strong influence of temperature on parameter $b^{*}$. Working with dried papaya obtained by osmotic dehydration and conventional air drying, Germer et al. (2014) stated yellow color (parameter $b^{*}$ ) degradation rates of 0.113 days $^{-1}\left(25^{\circ} \mathrm{C}\right)$ and 0.26 days $^{-1}$ $\left(35^{\circ} \mathrm{C}\right)$, besides shorter $\mathrm{t}_{1 / 2}$ values $\left(207\right.$ days at $25^{\circ} \mathrm{C}$ and 92 days at $\left.35^{\circ} \mathrm{C}\right)$ and lower $\mathrm{Q}_{10}(2.30)$.

The activation energy $\left(\mathrm{E}_{\mathrm{a}}\right)$ for the color parameter variations ranged from 14.88 to $19.19 \mathrm{kcal} / \mathrm{mol}$, close to the anthocyanin degradation value $(14.80 \mathrm{kcal} / \mathrm{mol})$ (Table 3). This result indicated that the effect of temperature on the kinetics of both color parameters and anthocyanins variations was similar. In the same way, the anthocyanin contents during the storage at $25^{\circ} \mathrm{C}$ showed good correlation with color parameters, resulting in the following Pearson coefficients: 0.90 for parameter a* (green/red); 0.85 for parameter $\mathrm{L}^{*}$ (black/white); and -0.84 for parameter $b^{*}$ (blue/yellow). As expected, the color of jabuticaba flakes was strongly related to the presence of anthocyanins, and the evaluation of these pigments in the product during the storage could eventually be done using instrumental color analysis, in particular by monitoring the parameter $\mathrm{a}^{*}$.

\section{Conclusions}

The sorption isotherm of the drum-dried jabuticaba flakes with cassava starch was adjusted by the GAB model, resulting in a monolayer moisture content $\left(\mathrm{X}_{\mathrm{m}}\right)$ of $0.1596 \mathrm{~g}$ water $/ \mathrm{g}$ dry basis (d.b.) at $25{ }^{\circ} \mathrm{C}$. The 
visual analysis of the product showed its stability regarding the physical changes (agglomeration and color) in $\mathrm{a}_{\mathrm{w}} \leq 0.33$ at $25^{\circ} \mathrm{C}$. The obtained degradation kinetics parameters indicated good stability for the flakes at the storage at $25{ }^{\circ} \mathrm{C}$ with half-life times, in terms of anthocyanin content and instrumental color, ranging from approximately 630 to 1450 days, respectively. The anthocyanin contents during the storage presented good correlation with color parameters, mainly with a* (green/red) parameter, showing a Pearson coefficient of 0.90 at $25{ }^{\circ} \mathrm{C}$. The activation energy $\left(\mathrm{E}_{\mathrm{a}}\right)$ for the variation of anthocyanin content and color parameters throughout the storage ranged from approximately 15 to $19 \mathrm{kcal} / \mathrm{mol}$, while the temperature acceleration coefficient values $\left(\mathrm{Q}_{10}\right)$ varied between 2.19 and 3.18, demonstrating the sensitivity of these properties to the temperature increase.

The jabuticaba flakes produced by the drum drying were rich in anthocyanins ( $\sim 100 \mathrm{mg} / 100 \mathrm{~g}$ d.b. $)$, total phenolic compounds ( $3100 \mathrm{mg} \mathrm{GAE} / 100$ g d.b.), besides high antioxidant activity $(\sim 220 \mu \mathrm{mol} \mathrm{TE} / \mathrm{g} \mathrm{d}$.b.) and can be used as an ingredient in the development of new formulations, such as bakery and confectionery products. However, the conservation of this product depends on the drying conditions, since it is important to obtain a product with a low water activity $\left(\mathrm{a}_{\mathrm{w}} \leq 0.33\right)$, combined with the use of a suitable packaging (barrier to $\mathrm{O}_{2}$, light and moisture gain), as well as mild temperatures $\left(\leq 25^{\circ} \mathrm{C}\right)$ at storage.

\section{Acknowledgements}

The authors are grateful to De Marchi Indústria e Comércio de Frutas Ltda. for providing the jabuticaba frozen pulp.

\section{References}

Association of Official Analytical Chemists - AOAC. (2006). Official methods of analysis of the Association of Official Analytical Chemists (18th ed.). Maryland: AOAC Press.

Azarpazhooh, E., Sharayei, P., Zomorodi, S., \& Ramaswamy, H. S. (2019). Physicochemical and phytochemical characterization and storage stability of freeze-dried encapsulated pomegranate peel anthocyanin and in vitro evaluation of its antioxidant activity. Food and Bioprocess Technology, 12(2), 199-210. http://dx.doi.org/10.1007/s11947-018-2195-1

Barbosa-Cánovas, G. V., Ortega-Rivas, E., Juliano, P., \& Yan, H. (2005). Food powders: Physical properties, processing, and functionality. Dordrecht: Kluwer Academic/Plenum Publishers.

Benvenuti, S., Pellati, F., Melegari, M., \& Bertelli, D. (2004). Polyphenols, anthocyanins, ascorbic acid and radical scavenging activity of Rubus, Ribes, and Aronia. Journal of Food Science, 69(3), 164-169. http://dx.doi.org/10.1111/j.13652621.2004.tb13352.x

Bezerra, T.S., Costa, J.M.C., Afonso, M.R.A., Maia, G.A., \& Clemente, E. (2011). Avaliação físico-química e aplicação de modelos matemáticos na predição do comportamento de polpas de manga desidratadas em pó. Revista Ceres, 58(3), 278-283. https://doi.org/10.1590/S0034-737X2011000300005.

Bhandari, B. R., Datta, N., \& Howes, T. (1997). Problems associated with spray drying of sugar-rich foods. Drying Technology, 15(2), 671-684. http://dx.doi.org/10.1080/07373939708917253

Brand-Williams, W., Cuvelier, M. E., \& Berset, C. (1995). Use of a free radical method to evaluate antioxidant activity. Lebensmittel-Wissenschaft + Technologie, 28(1), 25-30. http://dx.doi.org/10.1016/S0023-6438(95)80008-5

Brunauer, S. (1943). The absorption of the gases and vapors. Physical adsorption. Princeton: Princeton University Press.

Buvé, C., Kebede, B. T., De Batselier, C., Carrillo, C., Pham, H. T. T., Hendrickx, M., Grauwet, T., \& Van Loey, A. (2018). Kinetics of colour changes in pasteurised strawberry juice during storage. Journal of Food Engineering, 216, 42-51. http://dx.doi.org/10.1016/j.jfoodeng.2017.08.002

Caparino, O. A., Nindo, C. I., Tang, J., Sablani, S. S., Chew, B. P., Mathison, B. D., Fellman, J. K., \& Powers, J. R. (2017) Physical and chemical stability of refractance window ${ }^{\circledR}-$ dried mango (Philippine 'Carabao' var.) powder during storage. Drying Technology, 35(1), 25-37. http://dx.doi.org/10.1080/07373937.2016.1157601

Caparino, O. A., Tang, J., Nindo, C. I., Sablani, S. S., Powers, J. R., \& Fellman, J. K. (2012). Effect of drying methods on the physical properties and microstructures of mango (Philippine "Carabao" var.) powder. Journal of Food Engineering, 111(1), 135148. http://dx.doi.org/10.1016/j.jfoodeng.2012.01.010

Carvalho, C. R. L., Mantovani, D. M. B., Carvalho, P. R. N., \& Moraes, R. M. (1990). Análises químicas de alimentos - Manual técnico. Campinas: ITAL.

Ferrari, C. C., Marconi Germer, S. P., Alvim, I. D., \& de Aguirre, J. M. (2013). Storage stability of spray-dried blackberry powder produced with maltodextrin or gum arabic. Drying Technology, 31(4), 470-478. http://dx.doi.org/10.1080/07373937.2012.742103 
Fracassetti, D., Del Bo, C., Simonetti, P., Gardana, C., Klimis-Zacas, D., \& Ciappellano, S. (2013). Effect of time and storage temperature on anthocyanin decay and antioxidant activity in wild blueberry (Vaccinium angustifolium) powder. Journal of Agricultural and Food Chemistry, 61(12), 2999-3005. PMid:23489164. http://dx.doi.org/10.1021/jf3048884

Garcia, M. C., \& Franco, L. (2015). Effect of glycerol monostearate on the gelatinization behavior of maize starches with different amylose contents. Starch, 67(1-2), 107-116. http://dx.doi.org/10.1002/star.201400107

Germer, S. P. M., Ferrari, C. C., Lancha, J. P., Berbari, S. A. G., Carmello-Guerreiro, S. M., \& Ruffi, C. R. G. (2014). Influence of processing additives on the quality and stability of dried papaya obtained by osmotic dehydration and conventional air drying. Drying Technology, 32(16), 1956-1969. http://dx.doi.org/10.1080/07373937.2014.924963

Greenspan, L. (1977). Humidity fixed points of binary saturated aqueous solutions. Journal of Research of the National Bureau of Standards, 81(1), 89-96. http://dx.doi.org/10.6028/jres.081A.011

Instituto Adolfo Lutz - IAL. (2008). Métodos físico-químicos para análise de alimentos (4. ed.). São Paulo: IAL.

Karam, M. C., Petit, J., Zimmer, D., Baudelaire Djantou, E., \& Scher, J. (2016). Effects of Drying and grinding in production of fruit and vegetable powders: A review. Journal of Food Engineering, 188, 32-49. http://dx.doi.org/10.1016/j.jfoodeng.2016.05.001

Kurozawa, L. E., Park, K. J., \& Hubinger, M. D. (2009). Effect of maltodextrin and gum arabic on water sorption and glass transition temperature of spray dried chicken meat hydrolysate protein. Journal of Food Engineering, 91(2), 287-296. http://dx.doi.org/10.1016/j.jfoodeng.2008.09.006

Labuza, T. P., \& Altunakar, L. (2007). Water activity prediction and moisture sorption isotherms. In G. Barbosa-Canovas, A. J. Fontan junior, S. J. Schmidt \& T. P. Labuza (Eds.), Water activity in foods: Fundamentals and applications. New York: Blackwell Publishing. http://dx.doi.org/10.1002/9780470376454.ch5.

López-Vidaña, E. C., Rojano, B. A., Figueroa, I. P., Zapata, K., \& Cortés, F. B. (2016). Evaluation of the sorption equilibrium and effect of drying temperature on the antioxidant capacity of the jaboticaba (Myrciaria cauliflora). Chemical Engineering Communications, 203(6), 809-821. http://dx.doi.org/10.1080/00986445.2015.1107721

Moura, S. C. S. R., Tavares, P. E. R., Germer, S. P. M., Nisida, A. L. A. C., Alves, A. B., \& Kanaan, A. S. (2012). Degradation kinetics of anthocyanin of traditional and low-sugar blackberry jam. Food and Bioprocess Technology, 5(6), 2488-2496. http://dx.doi.org/10.1007/s11947-011-0578-7

Muche, B. M., Speers, A., \& Rupasinghe, H. P. V. (2018). Storage temperature impacts on anthocyanins degradation, color changes and haze development in juice of "Merlot" and "Ruby" grapes (Vitis vinifera). Frontiers in Nutrution, 5, 1-9. https://dx.doi.org/10.3389\%2Ffnut.2018.00100

Nindo, C. I., \& Tang, J. (2007). Refractance window dehydration technology: A novel contact drying method. Drying Technology, 25(1), 37-48. http://dx.doi.org/10.1080/07373930601152673

Nunes, L. P. (2019). Produção de flocos de jabuticaba por drum drying: Desempenho de diferentes coadjuvantes de processo e estabilidade (Dissertação de mestrado). Instituto de Tecnologia de Alimentos, Campinas. Retrieved in 2020, April 15, from https://ital.agricultura.sp.gov.br/arquivos/pos/dissertacoes/2019/Dissertacao\%20Larissa\%20Peixoto\%20Nunes.pdf

Nunes, L. P., Ferrari, C. C., Ito, D., Souza, E. C. G., \& Germer, S. P. M. (2020). Drum drying process of jabuticaba pulp using corn starch as an additive. Brazilian Journal of Food Technology, 23, e2019166. http://dx.doi.org/10.1590/1981-6723.16619

Oliveira, F. C., Marques, T. R., Machado, G. H. A., Carvalho, T. C. L., Caetano, A. A., Batista, L. R., \& Correa, A. D. (2018). Jabuticaba skin extracts: phenolic compounds and antibacterial activity. Brazilian Journal of Food Technology, 21, e2017108. http://dx.doi.org/10.1590/1981-6723.10817

Paglarini, C.S., Silva, F.S., Porto, A.G., Piasson, D., \& Santos, P. (2013). Histerese das isotermas de sorção da polpa de manga (Mangifera indica L.) variedade manteiga. Revista Brasileira de Engenharia Agrícola e Ambiental, 17(3), 299-305. https://doi.org/10.1590/S1415-43662013000300008

Park, K. J., Bin, A., \& Brod, F. P. R. (2001). Obtenção das isotermas de sorção e modelagem matemática pêra Bartlett (Pyrus sp.) com e sem desidratação osmótica. Ciência e Tecnolologia de Alimentos, 21(1), 73-77. http://dx.doi.org/10.1590/S0101 20612001000100016

Pérez-Alonso, C., Beristain, C. I., Lobato-Calleros, C., Rodríguez-Huezo, M. E., \& Vernon-Carter, E. J. (2006). Thermodynamic analysis of the sorption isotherms of pure and blended carbohydrate polymers. Journal of Food Engineering, 77(4), 753-760. http://dx.doi.org/10.1016/j.jfoodeng.2005.08.002

Pitalua, E., Jimenez, M., Vernon-Carter, E. J., \& Beristain, C. I. (2010). Antioxidative activity of microcapsules with beetroot juice using gum arabic as wall material. Food and Bioproducts Processing, 88(2-3), 253-258.

http://dx.doi.org/10.1016/j.fbp.2010.01.002

Rufino, M. S. M., Alves, R. E., Brito, E. S., Moraes, S. M., Sampaio, C. G., Pérez-Jiménez, J., \& Saura-Calixto, F. G. (2007). Metolodogia científica: Determinação da atividade antioxidante total em frutas pela captura do radical livre ABTS•+. Fortaleza: Embrapa Agroindústria Tropical.

Shui, G., \& Leong, L. P. (2006). Residue from star fruit as valuable source for functional food ingredients and antioxidant nutraceuticals. Food Chemistry, 97(2), 277-284. http://dx.doi.org/10.1016/j.foodchem.2005.03.048

Tonin, I. P., Ferrari, C. C., da Silva, M. G., de Oliveira, K. L., Berto, M. I., da Silva, V. M., \& Germer, S. P. M. (2018). Performance of different process additives on the properties of mango powder obtained by drum drying. Drying Technology, 36(3), 355-365. http://dx.doi.org/10.1080/07373937.2017.1334000 
Tonon, R. V., Baroni, A. F., Brabet, C., Gibert, O., Pallet, D., \& Hubinger, M. D. (2009). Water sorption and glass transition temperature of spray dried açai (Euterpe oleracea Mart.) juice. Journal of Food Engineering, 94(3-4), 215-221. http://dx.doi.org/10.1016/j.jfoodeng.2009.03.009

Tonon, R. V., Brabet, C., \& Hubinger, M. D. (2010). Anthocyanin stability and antioxidant activity of spray-dried açai (Euterpe oleracea Mart.) juice produced with different carrier agents. Food Research International, 43(3), 907-914. http://dx.doi.org/10.1016/j.foodres.2009.12.013

Wrolstad, R. E., Skrede, G., Lea, P., \& Enersen, G. (1990). Influence of sugar on anthocyanin pigment stability in frozen strawberries. Journal of Food Science, 55(4), 1064-1072. http://dx.doi.org/10.1111/j.1365-2621.1990.tb01598.x

Wu, S., Long, C., \& Kennelly, E. J. (2013). Phytochemistry and health benefits of jaboticaba, an emerging fruit crop from Brazil. Food Research International, 54(1), 148-159. http://dx.doi.org/10.1016/j.foodres.2013.06.021

Yamato, M. A., Silva, V. M., Souza, E. C. G., Ferrari, C. C., \& Germer, S. P. M. (2020). Stability of mango flakes obtained by drum drying with different additives. Drying Technology, 38(3), 361-375. http://dx.doi.org/10.1080/07373937.2019.1571505 